off the crop in a shorter time, when the grinding may
be continued until 8 or 9 P.M. On many plantations with a small mill and large
crop work might advantageously be carried on day and night, as mature cane ganeraily begins to deterio.

only fuel, and of ten one-fourth, at least, is net the sumed; but the question of bagasse burning deserves These remarks on son, so I will not deal with it here. These remarks on sugar making are intended to ap-
ply only to the sugar houses on this island (Hawaii). Where irrigation is practicable, the quality of thejuice
is, I think, generally of poorer quality than here, where we depend on the rainfall entirely. SHOREY,
EDMUND C. SHOP

Kohala, Hawaii, September, 1893 . EDMUND C. SHOREY
Chemist Kohala Sugar Co.

"AMEN" MUMMY COFFINS IN THE BRITISH MUSEUM.

THE Khedive has presented the British Museum with
four mummy coffins of great interest. Egypt has four mummy coffins of great interest. Egypt has given us many surprises, 1887 and 1891 . In the former vear the royal mummies, including those of Thothmes discovered. In 1891 the still more wonderful find was made of the mummies of the priests and priestesses
of the order of Amen. Scholars at once associated these two results of research with each other. The places, showing that there wust have been a reason most remarkable chapters of the religious and secu-
lar history of the world centers, the order of Amen
having been probably the most powerful and perfectly having been probably the most powerful and perfectly
organized ancient sacerdotal order. The discovery of
1891 was tade by M. Grebaut in the immediate neigh1891 was made by $M$. Grebaut in the immediate neigh-
borhood of Deir-el-Bahari, where he found a well giving access to an immense tomb, in which were 163 coffins of members of the confraternity of Amen There were also a number of ushabti figures and
statues of - Isis and Nephtys, the latter being hollow and containing papyrus rolls. All these objects were
removed to the museum at Ghizeh, where the larger portion are now on exhibition. But the Khedive and the museum authorities decided to present the surplus coffins to the European powers which hat ingly a few months ago a raffe was held at Ghizeh
and four of the coffins and some other objects fell to the lot of the British Museum. The coffin of a priestess in the museum is that of Tenthansf. and is of Egyptian work, probably of the twenty-second dynasty. The paintings which decorate it are otler coffin is that of a priest whose name is unknown, temple. Like that of the priestess, it is richly decorated. twenty-second dynasty. Along with the objects or twenty-second dynasty. Along with the objects pre-
sented to the museum are a pair of sepulchral boxes sented to the museum are a pair of sepulchral boxes and are adorned with mythological scenes. These to the collection of the British Museum; it would, incontain some specimens of the work of this great order of Amen.

\section{MICROSCOPICAL NOTES.}

Carmalum.-This is the name given to the most recent carmine stain for histological purposes. It has
been devised by Dr. Paul Maver, and is very easily prepared. One gramme of carminic acid is placed in a suitable vessel, together with ten grammes of am-
monia alum and 200 c. c. of distilled water. The mixture is then heated nearly to boiling point, until solution is effected, and, after cooling, carefully decanted
or filtered, when it is ready for use. The addition of a small crystal of thymol keeps the solution free from staining power and like picrocarmine will stain objects satisfactorily that have been fixed in osmic acid. the nucleus (Nat. Science, iii., 113)

Aniline Stains. - A general recipe for these stains, recommended by Hermann and said to serve equally fuchsine $\mathbf{S}$, dahlia, and orange $G$, is as follows: Stain-

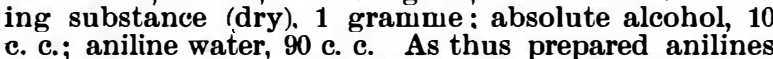
are said to stain very intensely and sharply. Washing out should be done in absolute alcohol, though with
safranine acid alcohol may be used. The solutions require to be used fresh, as they do not keep very long (Nat. Science, iii., 121). Staining Connective Tissue. - Pharmacists who are
called upon by medical practitioners and others to prepare animal tissues for microscopic examination may find Beneke's process for staining connective
tissue a useful one. It is a modification of Weigert's tissue a useful one. It is a modification of Weigert's
method for staining fibrin, and by means of it Beneke claims that the connective tissues of the most diverse organs can be consistently stained. Portions of tissue that has been fixed in alcohol, having been embedded in paraffin and cut, the sections are attached to slides in the usual way and stained for ten to twenty
minutes with aniline gentian violet (aniline oil, 10 parts, well shaken with water, 100 parts, then filtered, and concentrated alcoholic gentian violet solution, 5 to one minute with lugol solution of a port wine tint, dry with filter paper, and decolorize with aniline xylo
(aniline oil, 2 parts, xylol, 3 parts). Deeolorization having been stopped at the right point, which must balsam. The fibers of the connective tissue should apgem. Path., through B. M. J. Epit., p. 40)

Bleaching Sections.-An ingenious method of bleaching histological sections before staining is described by a bottle of 80 per cent. alcohol, having a layer of po- tassium chlorate crystals at the bottom. A few drops 'agreeable, refreshing and sharpish taste in summer,
of concentrated hydrochloric acid are then cautiously and that inakes beer and champagne foan. added and the bottle is subjected to a gentle heat.
The chlorine evolved is said to bleach sections in about preparation of carbonic acid is very simple. Let
is put a few pieces of chalk and some kind of acid Fixing Microscopic Ubjects on sides.-To fix minute (vinegar, for example) into a bottle, and close the lat-
ter with a cork provided with a tube to lead the disbjects in a definite position on a glass slide $J$. Tempere applies to the particular part of the surface of the
latter, after warming (at about $40^{\circ}$ to $50^{\circ}$ ), to remove all traces of moisture, a drop of a medium prepared by 100 grammes of absolute alcohol, and decanting off the hard transparent coating is left. This may be slightly hard transparent coating is left. This may be slightly
softened at any time by means of a drop of oil of spirit lamp will cause the oil to evaporate, leaving
sing them firmly attached. Objects may be mounted on cover glasses in a similar way. A resinous mounting If glycerin or glycerin jelly be the mounting medium used, collodion diluted with two or three times its
volume of oil of lavender may be found preferable as he fixing agent. The sections, etc., should be placed
thend in position before the preparation dries and the oil preparateur, i., 81).

\section{A WIREWORM TRAP.}

THE wireworm is one of the most troublesome pest

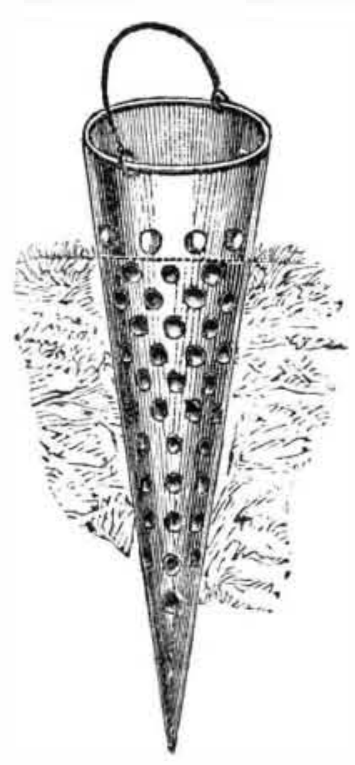

WIREWORII TRAP. enged gas to a receiver.

It may also be prepared by pouring water upon a moda and tartaric acid. This process is employed in families for the preparation of artificial seltzer water. Upon uncorking a bottle of carbonic water and quickly closing it with a cork provided with a bent tube, a small quantity of carbonic acid gas, quite eured.

By means of one of the producing apparatus mena large jar, but in such a way as not to fill the latter comple although the level of the gas cannot be ognized approximately by means of a candle attached This is the point of separation of the acid and air. Let us then blow the smoke of a cigarette gently air the surface of the gas, and we shall see it form wave and float, so to speak, upon the carbonic acid, and, upon shaking the jar, we shall plainly see its level blown upon it. In an instant we shall witness a curious phenomenon: the gas will diffuse itself in very visible wreaths upon a black ground, each of Which
erminates in a toadstool-like appendage. These vortices will descend slowly to the bottom of the jar.

THE MAKING OF MOUNTAIN CHAINS. By H. G. WeLLS, B.Se.

WrTHIN the past decade speculation upon the process of mount af attention from geologists. With in creased stratigraphical knowledge it has been possible to trace the successive stages in the life of an elevated
region with increased certainty, and a great and growregion with increased certainty, and a great and grow-
ing quantity of collateral information has been collect ed upon volcanic phenomena, earthquakes, the microed upon volcanic phenomena, earthquakes, the micro-
scopic structure of rocks and the behavior of viscous bodies under pressure. The history of every mountain range seems to resolve itself into the story of an incessant struggle betwe land emerges from the sea the forces of denudation begin to act upon it; as the upheaving powers win for a time and the land gradients increase, erosive acline is approached, and at last the Titanic forces of elevation, the strength of the caryatid giant, old Seis-
mos, becomes exhausted and the record of $h$ is efforts mos, becomes exhausted and the record of his efforts
is slowly erased by the at last triumphant forces of the
air. This, in brief, is the life history of every moun-
tain

for its destruction none is really effectual. Gas lime, if used sufficiently strong to kill the wireworm, kills the plants. The only eff ectual way of dealing with them
to catch them. Messrs. Osman \& Co., 132 and 134 commercial Road, E., have introduced a most effectual trap in the form of a perforated cone, made of
sheet iron, into which a carrot is inserted, and the cone thrust into the ground, as in the accompanying ing the past six weeks, and find that they quickly clear the ground of this enemy of carnations. I am
putting down two dozen more on some new ground I hibited at the Ap for carnations. I saw the traps ex and bought a dozen for trial ; and I believe I am doing public benefit in drawing attention to this little ers' Chronicle.

TOBACCO SMOKE FLOATED UPON CARBONIC ACID.

COAL, on burning incompletely in the air, yields

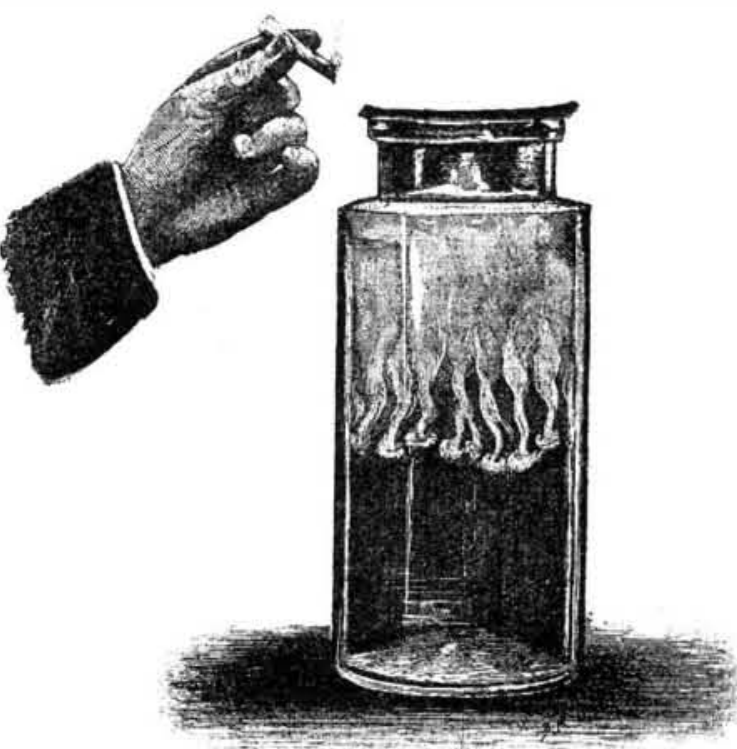

TOBACCO SMOKE FLOATED UPON CARBONIC ACID.

Somewhere in Swedenborg's writings there is an ac dead. They did not ask the man questions or subject and to cross-examination. They simply took his body, out to him all the things he had done. If I remember rightly, they began by "unrolling his fingers." What in their structure, and whatever thought had passed through his brain had made its infinitesimal difference
there. This is precisely the way the scientific man there. This is precisely the way the scientific man
hopes at last to build up the history of the past. Every hill, every pebble, every microscopic patch in a hornblende, rightly interpreted, bears its witness to the cosmic forces that have been at work upon them; tains in this way, so far as our light permits We may
best begin by remarking upon a few of the most significant features of existing nountain masses.
Perhaps in the order of their importance one should first notice the fact that almost all our great mountain chains have, high up upon their flanks, rocks of comparatively recent origin, and that we often find great paratively recent origin, and that we often find great
thicknesses of such rocks. The very summit of Mont
Blanc, for instance, was once surmounted by Jurassic Blanc, for instance, was once surmounted by Jurassic
rocks. Cretaceous rocks crown the Rocky Mountains, rocks. Cretaceous rocks crown the Rocky Mountains,
and tertiary masses lie at great elevations upon their twenty thousand feet on the Himalayas, and still younger pliocene formations lie high on their slopes. The elevated molasse of the Alps is a middle tertiary rock Not one of the really great mountain chains of the globe appears to have been elevated, or, indeed, each was an area of deposition, and further, of substrata, witnesses. So that we must figure for the beginning of our story a sea, near land indeed, or strata would not accumulate, and with a sinking bottom, or
its silting up must have occurred in the place of conits silting up must have occurred in the place of conOf course, when we state that the early tertiary and
thusus reader must understand we mean recent relatively to the length of geological periods. The date of accumulation of these sediments is certainly a matter of hunMr. Mellard Reade has insisted particularly upon the importance of this fact of the comparatively modern indeed, propounded a theory of the origin of mountain elevation largely based upon this. As everybody knows, there is within the earth an enormous store of heat; for instance. near the surface for every fifty feet
or so we go down the temperature rises $1^{\circ}$. The temand so much the more dangerous in that there is no perature of the surface-disregarding 8olar radiation
odor to announce its presence; when, on the con- -is the net result of two processes; heat must be conodor to announce its presence; when, on the con- is the net result of two processes ; heat must be con-
trary, the combustion is complete, the gas produced tinually arriving from the hotter interior bv conduc-
is carboric acid. Although less poisonous than oxide tion, and heat must be continually escaping by radiaof carbon, it announces its presence by a slight prick- tion into space.

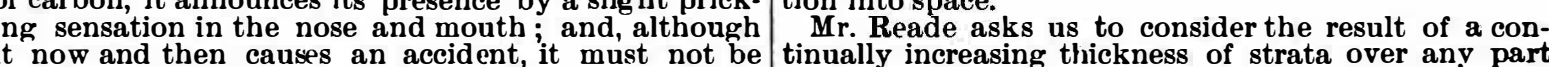
forgotten that it is what gives seltzer water its so of the earth's surface. It will act, just as a blanket 
does, by preventing the escape of heat. The rocks be
low will in time grow warmer, since they are no longe low will in time grow warmer, since they are no longer sill also be heated. The whole mass will expand horizontally and vertically, the movement of subsidence
will finally cease, and at last, as a consequence of the lateral strain, the horizontal strata will bulge and bo ridged upward into the form of mountain masses.
More striking, perhaps, than the recent age of the More striking, perhaps, than the recent age of their
constituent strata, and almost equally significant, is We cannot do better than call attention here to the accompanying figure of that classical example, Mont Blanc. The strata, the reader will see here, have been folded and folded again, and their ridges have been
denuded. If one takes the edges of a sufficiently flex. ible book and approximates the ends, one may imitate these foldings roughly, but they may be imitated st 11
better by compressing layers of cloth laterally beneath a weight.

ogy are wross all the elementary presumptions of geolhave been deposited horizontally. Since their deposition, therefore, their extremes have been brought to a squeezing in from the sides. It has been calcuside of this mountain mass have been brought closer to one another by as much as seventy two miles.
In the case of the Apvalachian Mountains the estimate is eighty-eight $m$ les. We seem to have here,
then, the clear record of the successive stages in such a process as is indicated in a simplified fashion by our phases in a steady lateral compression and D repeats
$\mathrm{C}$ with some allowance for the action of sub-aerial denudation.

It is upon this aspect of mountain structure that Prof. Lapworth laid particular stress in his memor-
able address to the Geological section of the British able adress to the Geological Section of the British
Association. He insisted upon the horizontal presweakest points, bulging up into ridges and furrows, and with further compression folding over, so that we get at last "over-folds" (Fig. 1), with an upthrust
or arch limb, a middle portion, and a down thrust or trough limb. The middle portion must especially be
under great pressure, and it may undergo crushing, under great pressure, and it may undergo crushing,
or the fold may rupture and the arch slide forward over the fault to form a reversed fault or over-faul or thrust plane as in Fig 5 . The final result of this weak point by more than doubling its thickness, and adjacent portions of the strata will then begin to
pucker. So that in the flanks of the original fold pucker. So that in the flanks of the original fold
fresh folding will ar se unt 1 we get either a fan-like series (as in Mont Blanc) or a one-sided arrangement Jura Mountains is displayed in the Appalachian and The causes of these mountain foldings may possibly be the lateral stress due to local horizontal expansion,
if the theory of Mr. Mellard Reade is correct. But $a$ great number of geologists consider that the prime
cause of these foldings, and indeed of mountan up-
heavals, is the contraction of the earth due to its secular cooling. As this contraction goes on the cold crust has to accommodate itself to the shrinking intecrust and in doing this it is necessarily crumpled and
rior, and
wrinkled. The great land masses and the great oceanic troughs of our earth, moreover, lie along lines of longitude. Winchell has attributed this north and
south trend of the chief 1 nes of crumpling to the diretive influence of the tidal stress. Prof. Lapworth. in his address, stated the case
for the contraction theory of mountain origin in a remarkably vivid way. He called attention to the manner in which trough and ridge everywhere corre-
sponded. For the upthrust of America, with its sponded. For the upthrust of America, with its
Mississippi Valley and its unilateral ridges of the
Rockies and Appalachians, we have the Atlantic with its division by the Dolphin ridge into two parallel troughs; and corresponding to the broad uprise of
the older continents we have the great depression of
the Pacific Coming to the shorter transverse foldthe Pacific. Coming to the shorter transverse fold-
ings, the Alpine mass had for its trough the Mediterranean ; and Central Asia the southward deep of the the solid earth is far more in agreement with the lard Reade. On the other hand, there are those who consider the
amount of folding we find in mountain masses, which amount of folding we find in mountain masses, which must amount altogether to a
circumference by many hundred miles, too great for
their conception of the amount of contraction the world has undergone since the rocks in question were solidified. Moreover, in certain localities in Sweden
and elsewhere, crumpled rocks are found lying on an undisturbed base. Prof. Rever has recently propounded some novel and remarkably suggestive views
in this matter. in this matter. or plaster of Paris mixed with glue and variously thinted. These before complete conool dation were
placed on boards slightly t lted $\left(5^{\circ}\right.$ to $\left.15^{\circ}\right)$, and the arrangement was occasionally tapped to imitate earth-
quake shocks. There was a general sliding down and quake shocks. There was a general sliding down and
crumpling of the mass, such as might conceivably crumpling of the mass, such as might conceivably
happen in the case of sedimentary rocks, and sections
taken after hardening showed, in consequence of this gliding, beautiful imitations of folding, contortion
and faulting such as are seen in mountain chains.
Such experiments Such experimentsas this might very easily be repeated by teachers of geology or physiography. They certhese physiographic problems. a series of mountain folds, based on experiments of
this kind, may be illustrated by the three figures
given. While it harmonizes with Mr. Mellard Reade's this tind, mas be illustrated by the three figures
given. While it harmonizes with Mr. Mellard Reade's
hypothesis, it seems perhaps a little better adapted
to explain complex crumpling of strata than does that to explain complex crumpling of strata than does that
supposition. A represents a continental mass, from
which the sedinents, C, D, F, accumulating in the
sea, B, are derived. For manifest reasons, these will be thickest and coarsest near land, where the carrying power of water is at its greatest. Now, on the phases. We can do without any appeal to "old Seis-
reasoning already given, this accumulation will finally mos" now to account for the elevation. A long n the region where the "blanket" s thickest. That
s to say, the base is tilted. The strata consequently
glide seaward and pucker up upon the tilted base
Fig. F). Meanwhile the coutinental mass (A) is con-
tinually undergoing denudation, and the rocks imme-
diately beneath, therefore, are cooling. We may say
that the young land to the right is pulling the
blanket off its older neighbor, the area, A. The cool-
ng of A causes a subsidence and faulting, and the
anlting, weakened, and sinking crust is there least
able to resist eruptive material, so that at last (Fig. 8)
a volcanic chain, F F F, may grow up beh nd the fold
chain.
This, briefly, is the story suggested b5 Prof. Reyer,

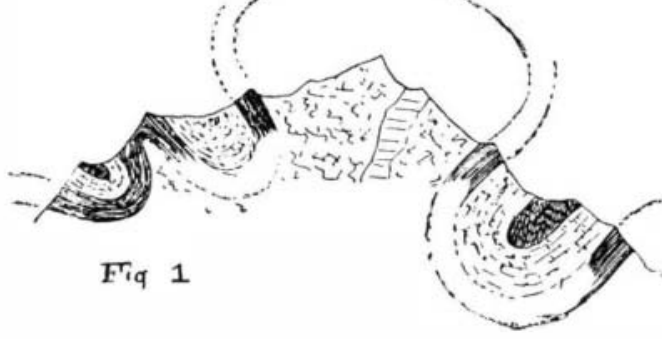

SECTION OF MONT BLANC.

a story also fairly consistent with existing mountain absolutely opposed to that so clearly propounded to the English student by Prof. Lapworth. The heat-
ing effect of deposition suggested by Mr. Mellard
Reade, the crust contraction to which Prof. Lapworth gives prominence, the "gliding " of Prof. Reyer, are
all causes that must operate. Prof. Reyer's theory may explain many cases of folding, Mr. Mellard Reade's many cases of upheaval, and yet the great
wrinkles on the face of Mother Earth may be due to her withering as the warmth of her youth departs Clearly, from what has been said, volcanic phetain chain. They do not, for instance appear to have played a leading part in Alpine history, and the great trachytic and basaltic outflows of that region
occurred. Volcanic forces cannot, therefore, for one moment be regarded as standing in a causative rela-

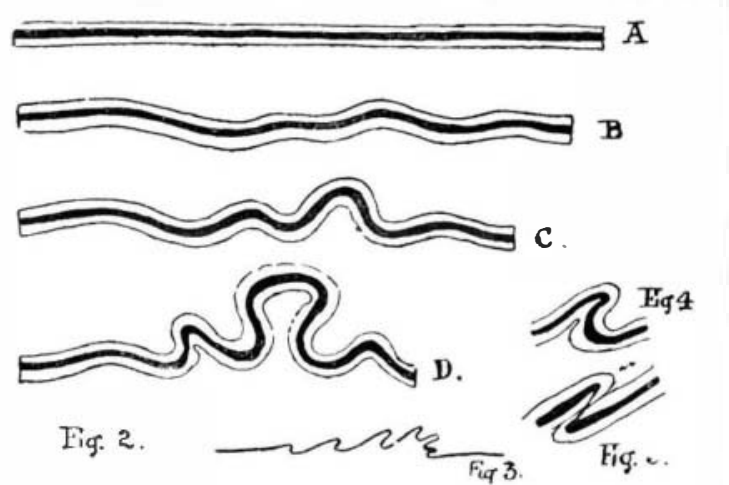

Andes and the Himalayas the abundant presence of
volcanoes is food for thought. However, the question of the causes of volcanic action scarcely belongs to Here we may allude to a third feature of mountain
tructure. It emphasizes the enormous pressures to wich the folded rocks were subjected. It is th
wich We find, for instance, clays, with all their once hig.
Weration of ledy-piggledy parlicles, twisted round into a direchat they can be split up into lamine, and are no onger clays but slates. Limestones lose the traces of
their organic relics and become recrystallized as marle. Some rocks are seen with their constituent mi nother, as though they had been through into on another, as though they had been through a colossa
crushing will (mylonitic structure). The quartz of ranite, for instance, is powdered, the feldspar cracked shredded. The rock has also been, as it were. mast cated in the presence of in-soaking water. Old mi
erals have been dissolved out, fresh ones formed.
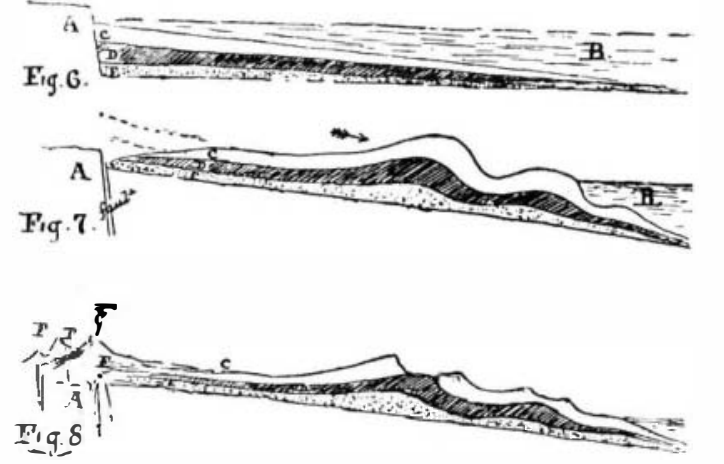

In some cases a parallel order of the minerals has been induced. It is as if the rock had become plastic here its lines of flow. Nothing could be more elomaking forces. It is interesting too to notice how would scarcely weigh a grain, the same story of enorwe find in considering the To summarize our deductions, we have in the hisWhases. Wean do without any appeal to "old Seis- firmly established, it was of necessity recognized that
wos" now to account for the elevation. A long such valleys changed in form, but the exact nature of per od of quiet subsidence and deposition of sediment is
followed by upheaval. There is a process of latera compression relieved by a bulging, the formation of a ridge or ridges, with troughs on either side. Probably there are no great paroxysms; the steady squeezabove the other, overfolds are formed. The rising mass slowly becomes a prominent terrestr al feature. by the formation of faults and thrust planes, and as the ruptured strata slip there are earthquakes. Rocks are sibly even liquefied. There may be volcanic out-
bursts along the axis or upon the margins of the rising area.
The emerging mass becomes subjected to denuda-
tion. In the main troughs which will be sinking beside the rising ridge, forming seas or lakes, sediments will accumulate. Presently these areas cease to subside
and become involved in a greater movement of eleSiwalik rocks on the Himalaya flanks. So the vast
growth continues. Strata tilted on its rising shoulders slide and are crumpled. Above, the snow and glacier are soon at work-unequal heating by day and fros
by night, rain and wind splinter the metamorphosed upturned rock masses into peak and pinnacle, cirque and precipice. Thus in the course of ages the moun-
tain chain attains its prime, and a brief equilibrium follows. ying awav or they have found a weaker area elsewhere. The volcanoes become extinct, the earth-
quakes less violent and less frequent. Every moment quakes less violent and less frequent. Every moment
a hundred streams carry away their quota of mate-
rial suspended or dissolved. So the period of decay rial suspended or dissolved. So the period of decay
sets in. From the still eruptive Hinalayas we may turn to the more quiescent Alps, from there again to the worn-down masses of Scandinavia and Scotland,
from there to the still more ancient mountain range half buried beneath the strata of Wales and central
England; and so the story ends at last as it began, in In conclusion, attention may be called to the rather remarkable fact that in the moon no great meridional
mountain ridges, such as one might expect from the mountain ridges, such as one might expect from the
analogy of the earth, are to be traced. Neither have analogy of the earth are to be traced. Neither have mountain axes. One might have anticipated, on the contrary. in the absence of an atmosphere and
atmospheric denudation and with feebler gravitainal attraction, that broad regions of crust folding would have been more conspicuous than on
the earth. It may be that these features have been masked by the subsequent precipitation of the lunar atmosphere; but the volcanic character of lunar
scenery is hardly consistent with this hypothesis. This, bowever, is a

\section{THE NEW PHYSICAL GEOGRAPHY.} By RALPh S. TARR.

AMONG the many instructive lessons which the study of the geology of the far West has taught, perhaps
the most important is the fact that physical geography and geology are inter-related sciences. If one
examine a text book of physical geography, he finds that it deals in the main with descriptions and statistics. A river is described as of three parts, the tor-
rential, valley and flood plain portions; it has a divide, perhaps a deelta, certain tributaries which rise here or
there; it flows in this or that direction, and empties into a certain sea or ocean; and it has a given length and drains so many thousand square miles of surface. In other words, the geographical side is fully preTurning now to the monographs of Powell, Gilbert, Dutton, Russell and others. one finds that land
form is regarded from the standpoint of origin and form is regarded from the standpoint of origin and
history, and that certain laws are stated by which which much progress has been made toward the fhich much progress has been made toward the fers, of physical geography. While some Germans and the establishment of this science, it may. I think, be
called essentially an American science, as it now called essentially an American science, as it now
stands. The writers named above, with Chamberlain, Salisbury, McGee, Davis and a few others, have shown how intimately land form is dependent upon tains, valleys, lakes and shore lines have all had a history which is readable, in part at least, by a study of
their form and position. By them geology is made to serve in the explanation of land form, and land the two sciences are made nterdependent. To each of these several writers much credit belongs for his part in the work, and it would be a task credit; but to Prof. Davis we owe much, not only for his original researches in the subject, but also formulaof physical geography he has been developing for years, with the aid of the other physingraphers, and geography which is serving as a model for similar is my purpose to state in outline some of the principles
of this science, as I interpret them, though in a short a presentation must of necessity be inUntil recently riter valleys have been looked upon as definite forms and in a measure unchangeable. instance, took part in the controversy which resulted ne nowly accepted view that river valleys were rmed not by faults or cracks in the earth, or by year, age by age. Strata are imperceptibly thrown vation, as is shown by the Swiss molasse and the 